University of California, Hastings College of the Law UC Hastings Scholarship Repository

Faculty Scholarship

1999

\title{
Domestic Violence and Children: Analysis and Recommendations
}

Lois A. Weithorn

UC Hastings College of the Law, weithorn@uchastings.edu

Lucy S. Carter

Richard E. Behrman

Follow this and additional works at: http://repository.uchastings.edu/faculty_scholarship

Part of the Juvenile Law Commons

\section{Recommended Citation}

Lois A. Weithorn, Lucy S. Carter, and Richard E. Behrman, Domestic Violence and Children: Analysis and Recommendations, 9 Future of Child. 4 (1999).

Available at: http://repository.uchastings.edu/faculty_scholarship/791

This Article is brought to you for free and open access by UC Hastings Scholarship Repository. It has been accepted for inclusion in Faculty Scholarship by an authorized administrator of UC Hastings Scholarship Repository. For more information, please contact marcusc@uchastings.edu. 


\title{
UNIVERSITY of CALIFORNIA HASTINGS COLLEGE OF THE LAW
}

\section{Faculty Publications}

UC Hastings College of the Law Library

\author{
Author: Lois A. Weithorn \\ Source: $\quad$ Future of Children \\ Citation: 9 FUtURE CHILD. 3 (1999). \\ Title: $\quad$ Domestic Violence and Children: Analysis and Recommendations
}

Originally published in FUTURE OF CHILDREN. This article is reprinted with permission from FUTURE OF CHILDREN and The Future of Children, Princeton-Bookings. 


\section{Domestic Violence and Children: Analysis and Recommendations}

T

oday, domestic violencel is recognized as a serious societal problem in the U nited States. Yet, children in families in which such violence occurs have remained largely invisible as victims. ${ }^{2}$ Concern about children's exposure to domestic violence 3 is increasing, however, in light of a growing body of knowledge regarding the prevalence and effects of childhood exposure to domestic violence. Research suggests that between 3.3 million and 10 million children in the United States are exposed to domestic violence each year. ${ }^{4}$ And more than a decade of empirical studies indicates that this exposure can have significant negative effects on children's behavioral, emotional, social, and cognitive development. ${ }^{5}$

Families affected by domestic violence touch all service systems and live in every community. Children exposed to domestic violence are in our schools, day-care centers, health care institutions, child welfare systems, and other agency settings. Law enforcement personnel have contact with children exposed to domestic violence through on-site police responses to domestic violence calls. Virtually every branch of our court system handles cases involving domestic violence. Though domestic violence cuts across the economic spectrum, poor families are more likely to be affected. 6 In fact, many families in which domestic violence is present struggle with multiple problems, including poverty, substance abuse, and exposure to other forms of violence. ${ }^{7}$ For example, current research indicates that in $30 \%$ to $60 \%$ of families experiencing either domestic violence or child maltreatment, the other form of violence is also present. 8

In response to the growing awareness of the potential harm to children exposed to domestic violence, a wide range of agencies and service providers are developing intervention policies and practices. Professional organizations, including the National Council of Juvenile and Family Court Judges, the American Bar Association, the American Medical Association, and the American Psychological Association, have published intervention recommendations, convened task forces, commissioned reports, or sponsored conferences to address this problem. ${ }^{9}$ Community-based domestic vio- 
lence organizations, many of which have served battered women and their children for more than two decades, have expanded their children's services to provide more comprehensive responses. Through cross-agency collaborations, innovative pilot programs are being implemented at various sites throughout the country to offer mental health services to children exposed to domestic violence and improve law enforcement responses to domestic violence incidences in which children are present. Policymakers are devoting increased attention to this issue, and several states have passed legislation, especially in the family law area, designed to improve outcomes for children exposed to domestic violence.

Though many of these approaches hold promise, few programs have been evaluated. It is difficult to find funding for intervention programs in this field, and even more difficult to obtain adequate funding for thorough evaluations. Yet, without this research, policymakers cannot determine which interventions yield the best results, and service providers do not have the quantitative information they need to improve programs and justify their long-term support.

This article summarizes the current knowledge to date regarding the prevalence and effects of childhood exposure to domestic violence. The article describes current responses to this problem by the multiple service systems with which children exposed to domestic violence have contact, and addresses what we know about how well these responses work. The article also discusses federal and state laws that affect these children and their families, proposes recommendations for improvements to these interventions, and explores strategies to prevent domestic violence. Despite the limitations in current research regarding the efficacy of programs for children exposed to domestic violence, the potential harms to these children necessitate action. Sweeping policy changes are premature, given our limited understanding of their potential impact. However, short of such changes, there is much work that can be done to improve interventions for children affected by domestic violence.

\section{Prevalence and Efiects of Child Exposure to Domestic Violence}

Researchers agree that millions of children are exposed to domestic violence each year; however, there is no consensus regarding the specific number of children affected. The often-cited figures of 3.3 million and 10 million are estimates derived from methodologically limited studies. ${ }^{10,11}$ This absence of trustworthy statistics on the prevalence of child exposure to domestic violence affects the ability of policymakers, practitioners, and advocates to argue for and design effective interventions and policies for this population. 
One promising approach to improving understanding about the prevalence of childhood exposure to domestic violence is to use data gathered by professionals in close contact with domestic violent incidences (such as law enforcement officers). In their article, Fantuzzo and Mohr illustrate the value of such data. They describe a multicity research project in which investigators created a sample of study cases using domestic violence misdemeanors. ${ }^{7}$ Results indicated that children, particularly those under the age of five, were disproportionately present in households experiencing domestic violence, and that these homes were more likely to have other risk factors present as well, such as poverty, substance abuse, low educational achievement of the principal care provider, and single-female heads of household. Though this study shows the potential of using data gathered by professionals close to the violent incident, it was not a national study and did not include all types of domestic violence cases.

Exposure to domestic violence can have serious negative effects on children. ${ }^{5}$ These effects may include behavioral problems such as aggression, phobias, insomnia, low self-esteem, and depression. ${ }^{12}$ Children exposed to domestic violence may demonstrate poor academic performance and problem-solving skills, and low levels of empathy. ${ }^{13}$ Exposure to chronic or extreme domestic violence may result in symptoms consistent with posttraumatic stress disorder, such as emotional numbing, increased arousal, avoidance of any reminders of the violent event, or obsessive and repeated focus on the event. ${ }^{14}$ Retrospective studies indicate that there may also be negative effects in adulthood, including depression, low self-esteem, violent practices in the home, and criminal behavior. ${ }^{15}$

The effects of domestic violence can vary tremendously from one child to the next. The family situation, community environment, and the child's own personality may either strengthen the child's ability to cope or increase the risk of harm. For example, studies indicate that children exposed to both domestic violence and child maltreatment typically show higher levels of distress than children exposed only to domestic violence. ${ }^{16}$ Additional research is needed to determine if the presence of other stressors such as poverty, homelessness, substance abuse, and exposure to community violence exacerbate the negative effects of exposure to domestic violence.

Not all children exposed to violence suffer significant harmful effects. Based on research presented in the article by O sofsky concerning children's resilience in the face of community violence and war, it is likely that the most critical protective factor for a child is the existence of a strong, positive relationship between the child and a competent and caring adult. Children exposed to violence need to be able to speak openly with a sympathetic adult about their fears and concerns, and also, ideally, have someone intervene to improve the situation. Most children rely on one or both parents to provide nurturing support in the face of crises and emotionally challenging situations, ${ }^{17}$ but ongoing exposure to violence can sometimes hamper the parents' abilities to meet these needs. Parents living with chronic violence may feel emotionally numb, depressed, irritable, or uncommunicative, and thus may be less emotionally available to their children. ${ }^{18}$

In cases of domestic violence, in which one parent is a victim of the violence and the other is the perpetrator, children may be even less able to turn to their parents for support and reassurance. The limited research to date on resilience and exposure to domestic violence indicates that maternal functioning, particularly as it relates to the mother's emotional availability, may be critical to children's ability to cope with the exposure. ${ }^{19}$ Yet, battered mothers may be less emotionally available to their children because they are preoccupied with the violence and trying to stay safe, and/ or because they are experiencing depression. 20 Their parenting practices may be compromised in other ways as well. Studies of battered women's patterns of affectionate or aggressive conduct toward their children either reveal no differences when compared with control groups, 21 or suggest that battered women may use more punitive child-rearing strategies or exhibit aggression toward their children.22 The limited research to date on the relationship between battering fathers and their children indicates that these fathers may be less available to their children, less likely to engage in rational discus- 
sions with their children, and less affectionate than fathers who are not violent. ${ }^{21}$ Still, more research on the effects of domestic violence on parenting is needed. Because the battered parent can be a critical support for the child, and because children often have ongoing contact with the batterer, services must be available to help parents improve their interactions with their children.

If parents experiencing domestic violence are unable to meet their children's needs, a relationship with a caring adult who is closely connected to the child's home or school can be helpful. Children with good social and communication skills are more likely to be successful at developing these relationshipsthan children who do not have these skills.23 Further study is needed to identify which social supports are most helpful to children exposed to domestic violence, and in which situations. With better research, practitioners can shape prevention and intervention strategies to boost the protective factors that promote children's positive coping. ${ }^{24}$

\section{RECOMMENDATION}

- Research is needed that advances the current understanding of the prevalence and effects of childhood exposure to domestic violence, and the impact of resilience and risk factors, so that policymakers and practitioners can design interventions sufficient to address the size, nature, and complexity of the problem.

\section{Systems Responses to Children Exposed to Domestic Violence}

Familiesaffected bydomestic violence utilize the services of health care, child welfare, mental health, and law enforcement agencies, as well as the courts and community-based domestic violence programs. Interventions for children in these families vary from system to system and from program to program within each system. Current services reach onlya small percentage of the number of children exposed to domestic violence, ${ }^{25}$ and are typically not designed with the spe- cific needs of these children in mind. Though specially designed services for children exposed to domestic violence are limited, innovative programs within each of these systems do exist. Currently, little is known about the effectiveness of these programs in improving outcomes for the children they serve.

\section{Community-Based Domestic Violence Services}

Community-based domestic violence services emerged from the battered women's movement of the 1970s and 1980s. Early services focused primarily on providing shelter and advocacy to battered women. However, because most of the battered women utilizing these programs brought their children with them, many of these programs began providing services to the children as well. There are now more than 2,000 communitybased domestic violence programs, and more than 1,300 provide shelter. ${ }^{26}$ Approximately half of all shelter residents are children. ${ }^{27}$ A 1997 survey shows that $72 \%$ of all shelters currently offer some type of children's services. 28 These services range from child care to recreational activities to health care to mental health counseling, though the number of shelters offering each type of service is unknown.

Innovative shelter programs that specifically address childhood exposure to domestic violence include group counseling sessions for the children and special parenting classes for the battered mothers. ${ }^{29}$ Another promising approach is the use of child advocates who help child residents access the benefits and services they need, ensure that legal protections are in place for the children, and provide training to shelter staff on child development and the impact of domestic violence on children. ${ }^{30}$ Despite the array of services offered through shelters, most children affected by domestic violence do not have access to these services. Shelter programs are chronically underfunded and unable to meet the demand for services. ${ }^{31} M$ any battered women do not utilize shelters, either by choice or because these services are not available. ${ }^{32}$ Additionally, many shelters do not allow adolescent boys to enter as residents. Despite increases in recent years in the number of battered women accessing legal advocacy, counseling, and support groups through nonresidential 
programs, these services are less available to children. 33 Identifying children through their contact with other public systems will increase their access to services only if a wide range of children's programs, in addition to those offered through shelters, is available. As Saathoff and Stoffel emphasize in their article in this journal issue, communitybased domestic violence programs are beginning to work collaboratively with other agencies to develop more comprehensive responses to mothers and children affected by domestic violence.

\section{RECOMMENDATION}

- Stable public funding sources are needed to support comprehensive and coordinated community-based services for battered women and their children, as well as program evaluations and replication of effective interventions.

\section{Health Care Services}

In her article, Culross states that between $4 \%$ and $30 \%$ of women entering emergency departments are suffering from a domestic violence injury. ${ }^{34}$ In the early 1990s, in recognition of the high health costs associated with domestic violence, key professional health care organizations developed guidelines for identifying and responding to domestic violence. ${ }^{35}$ As a result, many health care institutions have established domestic violence screening and assessment protocols, although it is unclear to what extent health care professionals use them. Studies indicate, for example, that only a little more than half of the women who enter emergency rooms for domestic violence related trauma either discuss their domestic violence experiences or are questioned about them by health care professionals, 36 although many would disclose if asked. ${ }^{37}$ Because so many battered women have frequent contact with the health care system, it provides a critical venue within which to reach battered women and their children. ${ }^{38}$ In order for screening and assessment protocols to be used effectively, health care professionals need ongoing training about domestic violence and the use of the protocols. 39
Once women and children affected by domestic violence are identified, health care professionals must be able to either provide them with or refer them to appropriate services. Some health care institutions have routine screening for domestic violence and offer specialized domestic violence services in-house, such as safety planning and support groups for battered women 40 or therapeutic interventions for the children. ${ }^{41}$

\section{RECOMMENDATION}

- Because the majority of children exposed to domestic violence do not have access to services through traditional avenues such as battered women's shelters, new strategies for identifying and serving these children in other venues, such as health care institutions, must be developed.

\section{Mental Health System}

Mental health system approaches to children exposed to domestic violence range from crisis interventions to individual, group, and family therapy programs. ${ }^{42}$ Crisis interventions can include mental health professionals providing on-site counseling in the home following a domestic violence incident, or immediate assistance to a child who is having trouble adjusting to shelter life. Group programs can offer children a safe venue in which to talk about the violence, improve selfesteem, and develop safety skills.43 Individual therapy is indicated for children who show extreme symptoms, though approaches vary.14 Some programs emphasize the development of social problem-solving skills that are often impaired by chronic exposure to domestic violence. 42 Others employ therapy techniques used to treat posttraumatic stress disorder. ${ }^{44}$ Family therapy approaches may include counseling for mother and child, and referrals to other family support services. Because of the potential dangers, few family therapy programs include batterers. Those that do will only work with batterers who have done extensive work to change their violent behavior. 45

It is not known how many mental health programs for children exposed to domestic 
violence have been established, or how many children participate in them. As Groves discusses in her article, children exposed to domestic violence may receive mental health services without being assessed and treated for exposure to domestic violence. Although the American Psychological Association has recently focused attention on childhood exposure to domestic violence, and some mental health professionals have, for years, provided special services to battered women and their children, most mental health professionals do not receive training in identifying, assessing, or treating children exposed to domestic violence. Funding for mental health interventions is limited, and often only supports short-term treatment that will not adequately address the long-term symptoms these children may exhibit, or the myriad of other stressors in these children's families. Crime-victim programs in several states provide funding so that children exposed to domestic violence, as well as adult victims, can receive long-term mental health treatment. 46 Other innovative programs combine more traditional mental health services with housing and job assistance. ${ }^{47}$

\section{Child Protective Services}

Asmentioned above, research indicates that there is a high co-occurrence in families of child abuse and domestic violence. Yet, as Findlater and Kelly point out in their article, separate service systems with unique histories and treatment philosophies have developed to address each form of violence. Child welfare agencies are empowered by state and federal laws to investigate reports of child abuse and neglect, offer services to families, make case recommendations to the juvenile court, and place children in foster and adoptive homes. Services provided to families keep children at home whenever it is safe to do so, and return children who have been removed, once the harmful circumstances have been addressed. If efforts to return the child home fail and the juvenile court terminates parental rights, child protective services (CPS) will find a permanent placement, such as an adoptive home, for the child. Ensuring the safety of the child is the principal mandate of CPS. In contrast, though many community-based domestic violence programs offer services to children, they focus mainly on providing support to bat- tered women. And, while most CPS services are court-ordered, participation in community-based domestic violence programs is voluntary.

Despite these differences, growing recognition of the co-occurrence in many families of child maltreatment and domestic violence has resulted in greater willingness on the part of CPS staff and domestic violence service providers to work together. Collaborative efforts to date have identified beliefs common to both systems: (1) the presence of domestic violence in families is harmful to children, (2) the safety of the mother affects the safety of the child, and (3) perpetrators must be held accountable. 48 Innovative pilot programs are successfully integrating child welfare and domestic violence services.49 Approaches include screening for domestic violence in all child maltreatment cases, having battered women's advocates on CPS staff to provide case consultation to workers and domestic violence services to families, 50 and crossfield training for both CPS and domestic violence service providers. ${ }^{51}$ Though these pilot programs show promise as models for collaboration, recent research reveals that cross-agency training remains limited and many professionals in each system believe the intervention goals of the other system conflict with their own. In addition, agency policies in both fields are unclear about how to intervene when both forms of violence are present in a family. 52 In 1999, the National Council of Juvenile and Family Court Judges (NCJFCJ) published a set of guidelines for effective intervention in cases involving both child maltreatment and domestic violence. 53 These guidelines, developed by a committee of key experts in both fields, provide a framework through which local communities can design comprehensive, communitybased responses that include protectionsfor adult and child victims, support services for the families, and effective and enforceable legal interventions.

\section{RECOMMENDATION}

- CPS and domestic violence service organizations must develop clear protocols for intervening with families in which both 
domestic violence and child maltreatment are present, offering services that provide safety and stability to the child, support to the battered woman, and treatment and sanctions for the batterer.

\section{Legal System}

Legal-system interventions include responses by law enforcement personnel to calls of domestic violence, probation services for batterers, prosecution of criminal cases, and court decision making. These systems have been slow to recognize and respond to the presence of domestic violence in their caseloads, but many states now have laws and protocols to improve responses. Several new law enforcement and court programs address the impact of domestic violence on children.

Between 1992 and 1996, only about half of female victims of domestic violence reported their victimization to law enforcement. ${ }^{54}$ In $88 \%$ of these cases, there was either a police response or the victim went to the police station for help. This figure marks a considerable improvement in law enforcement responses compared to two decades ago when it was standard policy not to intervene in what were viewed as private disputes. Although police are typically the first professionals on the scene after a domestic violence incident has occurred, they have limited services to offer families. Law enforcement departments in several locales throughout the country have initiated specific programs to improve interventions, including cooperative arrangements with mental health professionals who, upon notification by police, appear at the scene of the domestic violence incident to assist child and adult victims. 550 ther strategies include police report documentation of a child's presence in the home, which automatically qualifies the child for state victims of crime funding for support services, 56 and specialized training in child development for law enforcement personnel. 55

Domestic violence issues appear in all areas of the judicial system, including criminal court, juvenile court, family court, and other civil courts. Despite the recent use in several locales of innovative approaches to handle these cases, there is still widespread misunderstanding by judges and other court personnel about domestic violence and its potential impact on children. New programs (1) provide training on domestic violence issues to judges, child advocates, mental health professionals, and other court personnel; 57 (2) offer coordinated, cross-agency responses to cases involving both domestic violence and child maltreatment; 58 (3) utilize specialized domestic violence courts; or (4) have a one-family, one-judge approach in which one judge hears all civil and criminal cases involving a particular family. ${ }^{59}$ To be effective, innovative court approaches should include comprehensive training for all court personnel, access to a wide range of family services, and supportive court administrative practices. 60 Judges can play an important leadership role in encouraging coordinated responses for children affected by domestic violence. 61

\section{RECOMMENDATION}

- Professionals who have regular contact with families and children, including teachers and child care workers, health and mental health care providers, law enforcement officers, child welfare workers, and court personnel, should receive ongoing training on domestic violence and its impact on children.

\section{Laws and Public Policies Affecting Children Exposed to Domestic Violence}

Federal and state policies in a wide range of areas affecting families may potentially have an impact on children exposed to domestic violence. These include, at the federal level, domestic violence laws as well as child protection and welfare reform legislation; and at the state level, criminal sanctions against batterers, civil protective orders, child protection laws, and child custody and visitation laws. Very few of these federal and state laws directly address the needs of children exposed to domestic violence, and those that do have not been evaluated to understand their short- and long-term effects on the well-being of these children and their families. 
Recent Federal Legislation

Three federal laws enacted in the 1990s mandate policy changes that are likely to affect children exposed to domestic violence: (1) the Violence Against Women Act of 1994 (VAWA),62 (2) the Personal Responsibility and Work Opportunity Reconciliation Act of 1996 (PRWORA), 63 and (3) the Adoption and Safe Families Act of 1997 (ASFA). ${ }^{64}$ VAWA directly addresses domestic violence, while PRWORA and ASFA have implications for the substantial number of families affected by domestic violence who are also involved with the welfare and/ or child protection systems.

VAWA provides for increased services to battered women, improvements in prosecution of criminal cases involving domestic violence, and support for better law enforcement and other systems' responses to domestic violence. To the extent that these provisions improve battered women's safety and access to support services, they are likely to have a positive impact on these women's children as well. However, as Matthews points out in her article, VAWA's direct emphasis on the needs of children exposed to domestic violence is quite limited. A new VAWA bill introduced in 1999 included provisions that directly and more comprehensively addressed children's needs, but was not enacted. A similar bill will be introduced in 2000.65

Between $20 \%$ and $30 \%$ of all families receiving cash assistance through welfare programs ( now called Temporary Assistance to N eedy Families) also experience domestic violence.66 PRWORA mandates that states impose time limitations, work requirements, and child support compliance on the receipt of cash assistance. The Wellstone/ Murray Amendment 67 to PRWORA, passed in 1997, addresses concerns regarding the ability of battered women to meet these new requirements. This amendment allows but does not require states to adopt exceptions to the time limits, work requirements, and child support compliance for domestic violence victims. These exceptions are important because they enable battered women who cannot meet the new requirements to access public assistance. Limited access to public assistance can severely affect a battered woman's ability to leave an abusive situation. 68 Since September 1998, some 49 states have in place some type of domestic violence exception or special procedures for domestic violence victims, though not all are as comprehensive as the amendment's recommendations. ${ }^{69}$ Even if not all battered women need or choose to use them, it is important that the exceptions not just be on the books, but be fully implemented by welfare workers and available to all battered women seeking public assistance. ${ }^{70}$

ASFA shortens the time lines within which CPS must develop permanent placements for children in the child welfare system, and creates fiscal incentives to place more foster children into adoptive homes once parental rights have been terminated. Though ASFA also renews requirements that CPS provide appropriate services to families whose children have been removed so that the children can possibly return home, it is unclear how these requirements are being interpreted by CPS and the courts. Matthews, in her article, raises concerns regarding the ability of battered women to regain custody of their children within the shortened time lines mandated by ASFA. Battered women leaving abusive situations may need more time than the law allows to ensure safety for themselves and their children, recover from the trauma of being battered, find a new home and job, and enhance their parenting skills. If improvements to the family's circumstances are not made within the time line, parental rights may be terminated, when it would be better for the children to stay in foster care a while longer before returning home. However, because appropriate services to battered women and their children are so limited, courts may decide that CPS has not provided the requisite servicesand grant exceptionsto the time lines for these families. Though ASFA's goal of placing foster children in permanent homes more quickly is laudable, decisions regarding placement must include attention to the particular issues families face, and the appropriateness of services provided. Timely services that address the needs of families experiencing domestic violence are likely to result in better outcomes for children who have been both abused or neglected and exposed to domestic violence.

\section{State Laws and Policies}

State laws provide for protective orders and criminal sanctions against acts of domestic 
violence, which if properly enforced can help keep battered women and their children safe. Child custody and child welfare policies that do not consider the presence of domestic violence in a family may result in arrangements that are harmful to the children.

\section{Criminal Sanctions}

Criminal law in all states contains provisions that authorize the arrest and prosecution of those who commit acts of violence, such as battery, assault, kidnapping, and attempted murder. ${ }^{71}$ Until recently, these laws were rarely enforced in domestic violence cases. 72 During the 1980s, however, some jurisdictions developed policies that require police to arrest perpetrators of domestic violence. 0 ther recent legislation expands the range of criminal behaviors related to domestic violence to include intentional harassment of victims through stalking. ${ }^{73}$ These new trends in state legislation are important because they send a message to batterers and society that domestic violence will not be tolerated, ${ }^{74}$ and because they make imprisonment of the batterer a possible means of protection for abused women and their children. In addition, research suggests that mandatory arrest policies may be successful in deterring future violence by some batterers.75 Antistalking statutes hold promise of empowering women and law enforcement to interrupt an escalating cycle of violence before an assault occurs.

\section{Civil Protective Orders}

Civil courts can issue protective orders prohibiting a batterer from approaching the adult victim, the children, and various locations, such as the home, the victim's workplace, or the children's school. In some states, these orders can also include child custody and visitation arrangements. Battered women may contact law enforcement to intervene if a batterer violates the order. The consequences to a batterer of violating an order vary from state to state. ${ }^{76}$

A recent study suggests that lack of enforcement by police and courts has limited the ability of protective orders to keep battered women and their children safe. 77 Nonetheless, protective orders are commonly used by battered women to protect themselves and their children. Protective orders can be effective only if battered women know they are available and can obtain them, if the orders are tailored to address specific safety needs, and if penalties for violations have sufficient teeth to deter batterers from violating them. Research indicates that battered women are more likely to succeed in obtaining protective orders if they are represented by legal counsel. 78

\section{RECOMMENDATION}

- Courts must be empowered to design and enforce protective orders that comprehensively address the safety needs of battered women and their children. All battered women must have access to affordable legal counsel, so that they can utilize available legal means to protect themselves and their children.

\section{Child Custody and Visitation Laws}

Child custody and visitation laws guide family court decisions in divorce cases, regarding where the child will live and whether the child will have ongoing contact with a noncustodial parent. To reach these decisions, courts analyze the particular case circumstances to determine which arrangements will be best for the child. As Lemon states in her article, courts are increasingly considering the presence of domestic violence in making these determinations. ${ }^{79}$ Nonetheless, there are several trends in current state custody law that can lead to decisions in cases involving domestic violence that are not in the best interests of the children. These trends include: (1) a statutory preference for joint legal custodyeven when one or both parents object; (2) friendly parent provisions, which allow the court to prefer the parent who appears more cooperative and willing to share parenting; and (3) mandatory mediation. 80 Joint-custody arrangements in family situations involving high levels of parental conflict are likely to have detrimental effects on the children. 81 Policies that favor the "friendly parent" may lead to custody decisions against the battered mother, if she is unwilling to consider joint custody. Mandatory mediation in domestic violence cases denies the dynamics of power and control that exist in these 
cases, and that are contrary to mediation goals of cooperation and compromise. ${ }^{82}$

Some state legislatures are recognizing that policies favoring joint legal custody, "friendly parents," and mandatory mediation may result in decisions and processes inconsistent with the children's best interests, and have adopted exceptions for domestic violence cases. 83 In addition, several states have passed new laws that create a presumption against the batterer having custody, and require that the batterer overcome the presumption against him by showing that he is a fit parent. In some states, there is also a presumption against unsupervised visitation for noncustodial parents who have committed domestic violence. ${ }^{84}$

\section{RECOMMENDATION}

- In child custody and visitation cases involving domestic violence, courts should consider in their analysis of the best interests of the child the potential impact on the child of ongoing exposure to parental conflict and violence.

\section{Child Protection Policies}

Though federal laws heavily influence state child protection laws and practice, states retain a great deal of freedom to define the parameters of state CPS work. Two types of state child protection legislation raise particular concern when applied to families experiencing domestic violence: (1) failureto-protect laws that allow courts to make a finding of child maltreatment when a parent does not protect her child from harm, and (2) policies that make childhood exposure to domestic violence per se child maltreatment.

Failure-to-protect laws stem from the premise that omissions in a parent's behavior can cause a child harm, and that parents have a duty to keep their children from harm. Filing failure-to-protect petitions against battered women blames the adult victim for the violence, assumes she can stop the violence, and denies the fact that many battered women make calculated decisions to stay with their abusers because they believe leaving could result in homelessness, lack of steady income, or even injury or death at the hands of the batterer.85,86 H owever, in child protection cases, the juvenile court has jurisdiction over the child only, and applies pressure to parents through the ability to terminate parental rights if child-rearing practices do not improve. This makes it difficult to hold batterers, who may not care about or have parental rights, accountable for the harm their violence causes the children. Under current laws, failure-to-protect claims against a battered woman who wants to retain custody of her children may be the only way to provide CPS protection if the child is in danger. With assessment procedures and services in place to address domestic violence in the family, CPS can assist families in improving the circumstances for the child. Unfortunately, because most CPS agencies do not have specific domestic violence assessment procedures, training for caseworkers, or services, CPS intervention through failure-to-protect claims may result in decisions that are not best for the children.

In an effort to address the potential harm to children exposed to domestic violence, some policymakers are considering whether such exposure should be per se psychological abuse.87,88 Proponents argue that such policies would create a clear mandate for CPS intervention in cases in which children may be psychologically harmed, and would hold batterers more accountable for the effects of their violence by making them per se child abusers. ${ }^{87}$ Opponents argue that such policies may dissuade battered women from seeking help for fear of losing their children, and may further burden an already overloaded child welfare system. ${ }^{89}$ Before per se child abuse laws are passed, a thorough investigation of their potential impact is needed. Per se child abuse laws do not give courts and agencies the flexibility needed to assess the particular circumstances of each domestic violence case and determine appropriate interventions based on that case-by-case analysis. In order to adequately address the wide range of circumstances existing within families with domestic violence, multiple, community-based response systems are needed that do not require court or CPS intervention. 


\section{RECOMMENDATION}

- In designing new laws to address the effects of childhood exposure to domestic violence, policymakers should assess the potential unintended negative consequences of these laws and weigh them against the benefits.

\section{Prevention Programs}

Prevention strategies are critical to reducing the impact of domestic violence on children. Domestic violence prevention theories to date have borrowed heavily from public health models, which emphasize understanding the causes of the problem and identifying strategies to address the causes. ${ }^{90}$ Wolfe and Jaffe outline in their article various prevention approaches for domestic violence that have developed as a result of differing opinions about its causes.

Researchers and advocates have identified as a critical barrier to prevention societal norms that condone domestic violence. ${ }^{91}$ Public beliefs that domestic violence is not wrong or harmful also undermine efforts to hold perpetrators accountable and make it difficult to garner support for tougher policies as well as funding for victims' services. Campaigns to improve the public's understanding of the harms of domestic violence have been utilized extensively by community-based domestic violence organizations. ${ }^{92}$ An evaluation of a national public education campaign launched in 1992 by the Family Violence Prevention Fund shows success in improving the public's understanding of domestic violence and its impact, but shows mixed results with regard to increasing people's willingness to act in response to domestic violence. 93

School-based prevention programs are popular because they can reach so many children and youths, reduce misunderstandings regarding domestic violence, give safety information and planning, and offer positive alternatives for conflict resolution and relationship development. ${ }^{44}$ Some programs also train school personnel so they can intervene appropriately when children disclose the presence of domestic violence in their homes. Preliminary evaluations of school programs suggest that these strategies can be effective in changing the beliefs of students with regard to domestic violence and in possibly altering behavior as well. ${ }^{95}$ Other promising prevention approaches target families and couples directly through home visiting programs, ${ }^{96}$ for example, or behavioral-cognitive therapy for new couples at risk of violence. 97

Funding sources for domestic violence prevention efforts are extremely limited; even scarcer are resources for adequately evaluating prevention programs. Domestic violence prevention is difficult because it requires behavioral and societal changes, and it is difficult to measure these changes. Nonetheless, effective prevention approaches are pivotal to protecting children from the harms of exposure to domestic violence.

\section{RECOMMENDATION}

- Increased and ongoing public support is needed to develop effective prevention programs that address the underlying causes of domestic violence.

\section{Conclusion}

Research indicates that millions of children are exposed to domestic violence and that the potential effects from this exposure are substantial. This information alone creates an imperative for action, despite the fact that we do not yet have empirical evidence to show which interventions work best. Public and private service agencies must expand efforts to reach children exposed to domestic violence with the best interventions the current knowledge will allow. At the same time, new and better research is needed to improve our understanding of the number of children affected by domestic violence, the nature of that impact, other factors that influence outcomes for these children, and the effectiveness of intervention strategies. Excellent work is being done throughout the country to design and implement programs for chil- 
dren exposed to domestic violence. Solid efforts to date by researchers, advocates, policymakers, practitioners, and others in this young field have greatly improved our understanding of the potential harms to these children. Greater public and private financial support for these efforts is needed, so that future work can build on the good work that has already been done, to reach more children exposed to domestic violence, with more effective and comprehensive responses.

Lucy Salcido Carter, J.D. Lois A. Weithorn, Ph.D., J.D. Richard E. Behrman, M.D.

1. The term domestic violence typically refers to violence between intimate partners, including marital partners, cohabiting partners, and former partners, as well as noncohabiting dating couples. By contrast, the term family violence, which encompasses a broader set of familial relationships, includes child maltreatment, elder abuse, violence between siblings, and intimate partner abuse. Though there has been variability in the range of behaviors included in definitions of domestic violence, increasingly the term domestic violence encompasses a full range of assaultive and coercive conduct. The articles in this journal issue, unless otherwise stated, employ this broader definition. In addition, because most adult victims of domestic violence are female and most perpetrators are male, the authors of the articles in this journal often refer to victims as female, and perpetrators as male, although these roles are sometimes reversed. See Chalk, R., and King, P.A., eds. Violence in families: Assessing prevention and treatment programs. Washington, DC: National Academy Press, 1998; National Council of Juvenile and Family Court Judges. Effective interventions in domestic violence and child maltreatment cases: Guidelines for policy and practice Reno, NV: NCJFCJ, 1999; The Bureau of Justice Factbook reports that $85 \%$ of domestic violence victims are women. Greenfield, L. Violence by intimates: Analysis of data on crimes by current or former spouses, boyfriends, and girlfriends. Washington, DC: U.S. Department of Justice, March 1998.

2. Holden, G.W., Geffner, R., and Jouriles, E.N., eds. Children exposed to marital violence Washington, DC: American Psychological Association, 1998, p. 1.

3. The terms exposure to domestic violence and witnessing domestic violence are often used interchangeably in the literature, and in this journal issue. Increasingly, however, researchers have begun to differentiate these terms, using witnessing to refer to being present in the room when the violence occurred, and using exposureto refer to the full range of experiences children can have in relation to domestic violence (such as hearing shouting in another part of the house, seeing the aftermath in injuries to their parents, trying to interrupt the violence, or being in a mother's arms when she is physically attacked). See Edleson, J.L. Children's witnessing of adult domestic violence. Journal of Interpersonal Violence (August 1999) 14:839-70; Wolak, J., and Finkelhor, D. Children exposed to partner violence. In Partner violence: A comprehensive review of 20 years of research. J.L. Jasinski and L.M. Williams, eds. Thousand O aks, CA: Sage Publications, 1998.

4. Carlson, B.E. Children's observations of interparental violence. In Battered women and their families. A.R. Roberts, ed. New York: Springer Publishing, 1984; Straus, M.A. Children as witnesses to marital violence: A risk factor for lifelong problems among a nationally represen tative sample of American men and women. Report of the 23rd Ross Roundtable Columbus, $\mathrm{OH}$ : Ross Laboratories, 1992.

5. For a comprehen sive review of the research, see note no. 3, Edleson.

6. Lyon, E. Poverty, welfare, and battered women: What does the research tell us? Available online at http:// www.vaw.umn.edu/ FinalDocuments/ welres.htm.

7. Fantuzzo, J., Boruch, R., Beriama, A., et al. Domestic violence and children: Prevalence and risk in five major U.S. cities. Journal of the American A cademy of Child and Adolescent Psychiatry (1997) 36:116-22.

8. Edleson, J.L. The overlap between child maltreatment and woman battering. Violence Against Women (February 1999) 5:134-54.

9. See, for example, Davidson, H. The impact of domestic violence on children. Washington, DC: American Bar Association, 1994; American Psychological Association. Violence and the family. Washington, DC: APA, 1996; American Medical Association. National conference on family violence: $\mathrm{H}$ ealth and justice. Conference proceedings. Washington, DC. Chicago: AMA, 1994.

10. The 3.3 million figure is based on a study sample that did not include two groups particularly at risk for domestic violence-families with children under age three and families in which 
parents were divorced. This study also used an overly narrow definition of domestic violence. See note no. 3, Edleson, p. 842.

11. The 10 million figure is derived from a study conducted in 1992 that used retrospective, self-report methods to survey individuals about the existence of domestic violence in their families. See note no. 4, Straus.

12. Jouriles, E.N., Norwood, W.D., McDonald, R., et al. Physical violence and other forms of marital aggression: Links with children's behavior problems. Journal of Family Psychology (1996) 10:223-34; Margolin, G. Effects of domestic violence on children. In Violenceagainst children in the family and the community. P.K. Trickett and C.J. Schellen bach, eds. Washington, DC: American Psychological Association, 1998, pp. 57-101.

13. Rossman, B.B. Descartes's error and post-traumatic stress disorder: Cognition and emotion in children who are exposed to parental violence. In Children exposed to marital violence G.W. H olden, R. Geffner, and E.N. Jouriles, eds. Washington, DC: American Psychological Association, 1998, pp. 223-56; H inchey, F.S., and Gavalek, J.R. Empathic responding in children of battered mothers. Child A buse and N eglect (1982) 6:395-401. See note no. 12, Jouriles, Norwood, McDonald, et al.

14. Silvern, L., Karyl, J., and Landis, T.Y. Individual psychotherapy for the traumatized children of abused women. In Ending the cycle of violence: Community responses to children of battered women. E. Peled, P.G. Jaffe, and J.L. Edleson, eds. Thousand Oaks, CA: Sage Publications, 1995, pp. 43-76.

15. Silvern, L., Karyl, J., and Waelde, L., et al. Retrospective reports of parental partner abuse: Relationships to depression, trauma symptoms and selfesteem among college students. Journal of Family Violence (1995) 10:177-202; Maker, A.H ., Kemmelmeier, M., and Peterson, C. Long-term psychological consequences in women of witnessing parental physical conflict and experiencing abuse in childhood. Journal of Interpersonal Violence (1998) 13:574-89.

16. See note no. 13 , Rossman. See also 0 'Keefe, M. Predictors of child abuse in maritally violent families. Journal of Interpersonal Violence (1995) 10:3-25.

17. Wills, T.A., Blechman, E.A., and McN amara, G. Family support, coping, and competence. In Stress, coping, and resiliency in children and families. E.M. H etherington and E.A. Blechman, eds. Mahwah, NJ: Lawrence Erlbaum, 1996, pp. 107-33.

18. Osofsky, J.D., and Fenichel, E., eds. Caring for infants and toddlers in violent environments: Hurt, healing, and hope. Zero to Three (December 1993/ January 1994) 14:1-48.

19. One study found that the mothers who were not depressed and appeared least stressed were more likely to have children who demonstrated higher levels of psychological adjustment. Hughes, H.M., and Luke, D.A. H eterogeneity in adjustment among children of battered women. In Children exposed to family violence G.W. Holden, R. Geffner, and E.N. Jouriles, eds. Washington, DC: American Psychological Association, 1998, pp. 185-222.

20. Hilton, N.Z. Battered women's concerns about their children witnessing wife assault. Journal of Interpersonal Violence (1992) 7:77-86. See also Patterson, G.R., ed. Depression and aggression in family interaction. Hillsdale, NJ: Lawrence Erlbaum, 1990.

21. Holden, G.W., and Ritchie, K.L. Linking extreme marital discord, child rearing, and child behavior problems: Evidence from battered women. Child Development (1991) 62:311-27.

22. Jouriles, E.N., Barling, J., and O 'Leary, K.D. Predicting child behavior problems in maritally violent families. Journal of A bnormal Child Psychology (1987) 15:165-73; Jaffe, P.G., Wolfe, D.A., and Wilson, S.K. Children of battered women. N ewbury Park, CA: Sage Publications, 1990; H olden, G.W., Stein, J.D., Ritchie, K.L., et al. Parenting behaviors and beliefs of battered women. In Children exposed to marital violence G.W. Holden, R. Geffner, and E.N. Jouriles, eds. Washington, DC: American Psychological Association, 1998, pp. 289-336.

23. Beeman, S.K. Critical issues in research on social networks and social supports of children exposed to domestic violence. Un published paper prepared for the Asilomar Conference on Children and Intimate Violence, Pacific Grove, CA, February 1999.

24. Hughes, H.M., and Graham-Bermann, S.A. Resilience in children who experience family violence. Un published paper prepared for the Asilomar Conference on Children and Intimate Violence, Pacific Grove, CA, February 1999.

25. Peled, E. Secondary victims no more: Refocusing intervention with children. In Future interventions with battered women and their families. J.L. Edleson and Z.C. Eisikovits, eds. Thousand O aks, CA: Sage Publications, 1996, pp. 125-53.

26. National Coalition Against Domestic Violence. About the National Coalition Against Domestic Violence Denver, CO: NCADV, 1999. See the Healthtouch Online for Better Health Web site at http:/ / www.healthtouch.com/ level1/ leaflets/ ncadv/ ncadv002.htm. 
27. For example, the statewide data for Illinois and $\mathrm{New}$ Jersey revealed that children constituted $52.2 \%$ and $54.4 \%$ of shelter residents, respectively. See Illinois Coalition Against Domestic Violence, The recap summary report (Fiscal Year 1997). Unpublished report available by calling the coalition at (217) 789-2830; N ew Jersey Coalition for Battered Women. 1997 annual report, p. 4. Unpublished report available by calling the coalition at (609) 584-8107.

28. National Coalition Against Domestic Violence. 1997 national directory of domestic violence programs: A guide to community shelter, safe home, and service programs. Washington, DC: NCADV, 1997.

29. See for example, Peled, E., and Edleson, J.L. Process and outcome in small groups for children of battered women. In Ending the cycle of violence: Community responses to children of battered women. E. Peled, P.G. Jaffe, and J.L. Edleson, eds. Thousand Oaks, CA: Sage Publications, 1995, pp. 77-96.

30. Hughes, H.M., and Marshall, M. Advocacy for children of battered women. In Ending the cycle of violence: Community responses to children of battered women. E. Peled, P.G. Jaffe, and J.L. Edleson, eds. Thousand Oaks, CA: Sage Publications, 1995, pp. 121-44.

31. The Commonwealth Fund. Addressing domestic violence and its consequences. Policy report of The Commonwealth Fund Commission on Women's $\mathrm{H}$ ealth. New York: The Commonwealth Fund, February 1998, p. 18.

32. Roberts, A.R. The organizational structure and function of shelters for battered women and their children: A national survey. In Battered women and their families. 2nd ed. A.R. Roberts, ed. New York: Springer Publishing, 1998, pp. 58-75.

33. Centers for Disease Control, National Center for Injury Prevention and Control. Inventory of services and funding sou rces for programs designed to prevent violence against women: Introduction, p. 14. Available online at http:/ / www.cdc.gov/ ncipc/ dvp/ vawprograms/ intro.pdf.

34. Wilt, S., and OIson, S. Prevalence of domestic violence in the United States. Journal of the American M edical Women's Association (May/ July 1996) 51:77-82.

35. For a list of the health care organizations that have published guidelines, see note no. 31, The Commonwealth Fund, p. 13.

36. See note no. 31, The Commonwealth Fund, p. 9.

37. Rodriguez, M.A., Bauer, H.M., M CL oughlin, E., et al. Screening and intervention for intimate partner abuse: Practices and attitudes of primary care physicians. Journal of the American M edical Association (August 4, 1999) 282:468-74.

38. Schechter, S. The battered women's movement in the U nited States: New directions for institutional reform. In Futureinterventions with battered women and their families. J.L. Edleson and Z.C. Eisikovits, eds. Thousand O aks, CA: Sage Publications, 1996, pp. 53-66.

39. Training programs are still the exception rather than the rule, even with emergency room staff. Lee, D., Letellier, P., McLoughlin, E., et al. California hospital emergency departments response to domestic violen ce: Survey report. San Francisco: Family Violence Prevention Fund, 1993.

40. National Council of Juvenile and Family Court Judges. Emerging programs for battered mothers and their children. Reno, NV: NCJFCJ, 1998, pp. 127-30.

41. Groves, B.M., and Zuckerman, B. Interventions with parents and caregivers of children who are exposed to violence. In Children in a violent society. J.D. O sofsky, ed. New York: Guilford Press, 1997, pp. 183-201.

42. Rosenberg, M.S., and Rossman, B.B.R. The child witness to marital violence. In Treatment of family violence: A sourcebook. R.T. Ammerman and M. Hersen, eds. N ew York: John Wiley and Sons, 1990, pp. 183-210.

43. See note no. 29, Peled and Edleson. See also Peled, E., and Davis, D. Groupwork with children of battered women: A practitioner's manual. Thousand Oaks, CA: Sage Publications, 1995.

44. These techniques can include encouraging the child to talk about the violence, unlearn negative thinking patterns, and understand how feelings and symptoms are linked to the violent event. See note no. 14, Silvern, Karyl, and Landis.

45. See note no. 42, Rosenberg and Rossman, p. 205.

46. See, for example, California Government Code §§ 13959-13969.4 (West 1998), which provide funding for mental health services for victims of violent crimes, including children affected by domestic violence. 
47. Jouriles, E.N., McDonald, R., Stephens, N., et al. Breaking the cycle of violence: Helping families departing from battered women's shelters. In Children exposed to marital violence G.W. Holden, R. Geffner, and E.N. Jouriles, eds. Washington, DC: American Psychological Association, 1998, pp. 337-69.

48. Schechter, S., and Ganley, A.L. Domestic violence: A national curriculum for family preservation practitioners. San Francisco: Family Violence Prevention Fund, 1995.

49. Aron, L.Y., and O Ison, K.K. Efforts by child welfare agencies to address domestic violence: The experiences of five communities. Chicago: The U rban Institute, 1998.

50. Whitney, P., and Davis, L. Child abuse and domestic violence in Massachusetts: Can practice be integrated in a public child welfare setting? Child M altreatment (May 1999) 4:158-66.

51. See note no. 49, Aron and Olson, pp. 79-80.

52. Montminy-Danna, M. The child protective and domestic violence services survey. 1998. Results unpublished. Available by contacting Ms. Montminy-Danna at (401) 847-6650 or montminm@salve.edu.

53. See note no. 1, National Council of Juvenile and Family Court Judges.

54. See note no. 1, Greenfield, p. 20.

55. See note no. 40, National Council of Juvenile and Family Court Judges, pp. 119-23.

56. See, for example, reporting forms for Berkeley, CA, available by contacting Officer Bill Judis at (510) 644-6848.

57. Keilitz, S.L. Domestic violence and child custody disputes: A resource handbook for judges and court managers. Williamsburg, VA: National Center for State Courts, 1997. See also Cal. Fam. Code $\S \S 1815,1816$ (West 1998) mandating domestic violence training for certain family court mental health professionals.

58. Lecklitner, G.L., Malik, N.M., Aaron, S.M., et al. Promoting safety for abused children and battered mothers: Miami-Dade County's model dependency court intervention program. Child M altreatment ( May 1999) 4:175-82.

59. Flango, C.R., Flango, V.E., and Rubin, H.T. H ow are courts coordinating family cases? Alexandria, VA: State Justice Institute, 1999, pp. 34-35.

60. Ross, C.J. The failure of fragmentation: The promise of a system of unified family courts. Family Law Quarterly (Spring 1998) 32:3-30.

61. See, for example, the Coordinating Council Project in New Hampshire, note no. 40, National Council of Juvenile and Family Court Judges, pp. 98-100.

62. Public Law 103-322, 108 Stat. 1796 (1994).

63. Public Law 104-193, 110 Stat. 2105 (1996).

64. Public Law 105-89, 111 Stat. 2115 (1997).

65. Information regarding VAWA legislation can be obtained through the NOW Legal Defense Fund Web site at http:/ / www.nowldef.org/ html or by calling (202) 544-4470.

66. Raphael, J. Keeping women poor: H ow domestic violence prevents women from leaving welfare and entering the world of work. In Battered women, children, and wefare reform. R.A. Brandwein, ed. Thousand Oaks, CA: Sage Publications, 1999, pp. 31-43; Raphael, J., and H aennicke, S. The Family Violence O ption: An early assessment (revised draft II). Chicago: Taylor Institute, September 1, 1998.

67. 42 U.S.C. § 602 (1997).

68. Brandwein, R.A. Family violence and social policy: Welfare "reform" and beyond. In Battered women, children, and weffare reform. R.A. Brandwein, ed. Thousand Oaks, CA: Sage Publications, 1999, pp. 147-172.

69. See note no. 66, Raphael and Haennicke.

70. See note no. 66, Raphael, p. 42; Davies, J. The new welfare law: State implementation and use of the Family Violence 0 ption. Paper developed by the National Resource Center on Domestic Violence, 1998, pp. 9-10. Available online at http:/ / www.vaw.umn.edu/ FinalDocuments/ welpol2.htm.

71. Klein, C.F., and Orloff, L.E. Providing legal protection for battered women: An analysis of state statutes and case law. H ofstra Law Review (1993) 21:801-1188.

72. Developments in the law: Legal responses to domestic violence. $H$ arvard Law Review (1993) 106:1498-1620. 
73. Salame, L. A national survey of stalking laws: A legislative trend comes to the aid of domestic violence victims and others. Suffolk University Law Review (1993) 27:67-102.

74. See, for example, Zorza, J. Mandatory arrest for domestic violence: Why it may prove the best first step in curbing repeat abuse. Criminal Justice (1995) 10:2-54.

75. See note no. 72, Developments in the law; National Institute of Justice and American Bar Association. L egal interventions in family violence: Research findings and policy implications. Washington, DC: U.S. Department of Justice, 1998, publication no. NCJ171666, pp. 37-38, 54-57.

76. Hart, B.J. State codes on domestic violence: Analysis, commentary, and recommendations. Reno, NV: National Council of Juvenile and Family Court Judges, 1992, pp. 19-27.

77. Finn, P. Civil protection orders: A flawed opportunity for intervention. In Woman battering: Policy responses. M. Steinman, ed. Lincoln, NE: University of N ebraska Press, 1991, pp. 155-89.

78. See note no. 9, Davidson.

79. National Council of Juvenile and Family Court Judges. Family violence in child custody statutes: An analysis of state codes and legal practice. Family L aw Quarterly (1995) 29:197-225; Reihing, K.M. Protecting victims of domestic violence and their children after divorce: The American Law Institute's model. Family and Conciliation Courts Review (1999) 37:393-405.

80. See note no. 79, National Council of Juvenile and Family Court Judges. See al so Dalton, C. When paradigms collide: Protecting battered parents and their children in the family court system. Family and Conciliation Courts Review (1999) 37:273-90.

81. Research on joint custody reveals that a high level of cooperation is necessary for these arrangements to succeed. Felner, R.D., and Terre, L. Child custody dispositions and children's adaptation following divorce. In Psychology and child custody determinations. L.A. Weithorn, ed. Lincoln, NE: University of Nebraska Press, 1987, pp. 106-53.

82. Gagnon, A.G. Ending mandatory divorce mediation for battered women. H arvard Women's Law Journal (1992) 15:272-94; Grillo, T. The mediation alternative: Process dangers for women. Yale Law Journal (1991) 100:1545-1610.

83. See, for example, lowa Code Ann. § 598.41 (1997) ; Texas Fam. Code Ann. § 153.131 (1997); Minn. Stat. § 518.17(1) (a) (13) (1998).

84. See note no. 79, National Council of Juvenile and Family Court Judges, pp. 208-10.

85. In fact, studies show that most battered women take active steps to protect their children, even if they do not leave their batterer. See Magen, R.H. In the best interests of battered women: Reconceptualizing allegations of failure to protect. Child M altreatment (May 1999) 4:127-35. See also Hilton, N.Z. Battered women's concerns about their children witnessing wife assault. Journal of Interpersonal Violence (1992) 7:77-86.

86. Studies show that a battered woman is in the most danger of harm from the batterer when she leaves him. See Jones, A., and Schechter, S. When love goes wrong: What to do when you can't do anything right. New York: HarperCollins, 1993.

87. See, for example, Echlin, C., and Marshall, L. Child protection services for children of battered women: Practice and controversy. In Ending the cycle of violence: Community respon ses to children of battered women. E. Peled, P.G. Jaffe, and J.L. Edleson, eds. Thousand Oaks, CA: Sage Publications, 1995, pp. 170-185. Echlin and Marshall point out that several Canadian provinces have such policies.

88. In addition, $U$ tah has passed legislation that criminalizes the commission of domestic violence in the presence of a child. Utah Code Ann. § 76-5-109.1 (1999). Although this law applies to criminal court only, and does not directly affect juvenile court intervention and CPS involvement, the statute reveals that some state legislators have concluded that the psychological effects of domestic violence on children are sufficiently damaging to be construed as per se abuse to the child.

89. See note no. 1, National Council of Juvenile and Family Court Judges, p. 10. See also note no. 85, Magen, p. 130, and note no. 25, Peled, pp. 134-36.

90. Saltzman, L.E., and Johnson, D. CDC's family and intimate violence prevention team: Basing programs on science. Journal of the American M edical Women's Association (May/ July 1996) 51:83-86.

91. Klein, E., Campbell, J., Soler, E., et al. Ending domestic violence: Changing public perceptions/ halting the epidemic. Thousand Oaks, CA: Sage Publications, 1997, pp. 88-90. 
92. A 1994 survey of 86 domestic violence coalitions throughout the country found that $92 \%$ of the identified programs include a public education component in their local prevention efforts. See note no. 33, Centers for Disease Control, $\mathrm{N}$ ational Center for Injury Prevention and Control, p. 13.

93. See note no. 91, Klein, Campbell, Soler, et al., pp. 90-101.

94. The state domestic violence coalitions survey found that $74 \%$ of programs provided some domestic violence education in the schools. See note no. 33, Centers for Disease Control, National Center for Injury Prevention and Control. See also Jones, L. The Minnesota school curriculum project: A statewide domestic violence prevention project in secondary schools. In Dating violence Young women in danger. B. Lewy, ed. Seattle: Seal Press, 1991, pp. 258-66.

95. See, for example, the evaluation of the My Family and Me-Violence Free program, note no. 94 , Jones.

96. See, for example, Duggan, A.K., McFarlane, E.C., Windham, A.M., et al. Evaluation of H awaii's H ealthy Start Program. The Future of Children (Spring/ Summer 1999) 9,1:66-90.

97. See, for example, Holtzworth-M unroe, A., Markman, H., O'Leary, K.D., et al. The need for marital violence prevention efforts: A behavioral-cognitive secondary prevention program for engaged and newly married couples. Applied and Preventive Psychology (1995) 4:77-88. 